\title{
Study on Effect of Different Tool Design \& Material in Friction Stir Welding
}

\author{
Nair Milind*, Midhun Antony*, Rakhil K*, Jithin Sunny V*, \\ Manoj Kumar V.K** \\ *(UG Scholar, Department of Mechanical Engineering, Jyothi Engineering College, Thrissur, India) \\ ** (Assistant Professor, Department of Mechanical Engineering, Jyothi Engineering College, Thrissur, India)
}

\begin{abstract}
Friction Stir Welding (FSW) is a solid state joining process that involves joining of metals without fusion or filler materials. The frictional heat is produced from a rapidly rotating non- consumable high strength tool pin that extends from a cylindrical shoulder. The process is particularly applicable for aluminum alloys but can be extended to other products also. Plates, sheets and hollow pipes can be welded by this method. The process is also suitable for automation. The weld produced is of finer micro structure and superior in characteristics to that parent metal. FSW finds application in shipbuilding, aerospace, railway, electrical and automotive industry. The limitations of FSW are reduced by intensive research and development. Its cost effectiveness and ability to weld dissimilar metals makes it a commonly used welding process in recent times.
\end{abstract}

Keywords: solid state joining, cylindrical shoulder, different tool material, FSW

\section{INTRODUCTION}

Welding is process of metal joining with the help of heat or without frictional heat. In addition to melting the base metal, a filler material is often added to the joint to form a pool of molten material (the weld pool) that cools to form a joint that can be as strong as the base material. Pressure may also be used in conjunction with heat, or by itself, to produce a weld. Many different energy sources can be used for welding, including a gas flame, an electric arc, a laser, an electron beam, friction, and ultrasound. While often an industrial process, welding may be performed in many different environments, including in open air, under water, and in outer space. Welding is a hazardous undertaking and precautions are required to avoid burns, electric shock, vision damage, inhalation of poisonous gases and fumes, and exposure to intense ultraviolet radiation.

A friction stir welding (FSW) tool is obviously a critical component to the success of the process. The tool typically consists of a rotating round shoulder and a threaded cylindrical pin that heats the work-piece, mostly by friction, and moves the softened alloy around it to form the joint. Since there is no bulk melting of theworkpiece, the common problems of fusion welding such as the solidification and liquation cracking, porosity and the loss of volatile alloying elements are avoided in FSW. These advantages are the main reasons for its widespread commercial success for the welding of aluminium and other soft alloys. However, the FSW tool is subjected to severe stress and high temperature particularly for welding of hard alloys such as steels and titanium alloys and the commercial application of

FSW to these alloys is now limited by the high cost and short life of FSW tools.

A method of solid phase welding, which permits a wide range of parts and geometries to be welded are called Friction Stir Welding (FSW). Friction stir welding has a wide application potential in ship building, aerospace, automobile and other manufacturing industries. The process proves predominance for welding non-heat treatable or powder metallurgy Aluminium alloys, to which the fusion welding cannot be applied. Thus fundamental studies on the weld mechanism, the relation between microstructure, mechanical properties and process parameters have recently been started. Friction stir welding as a joining technology capable of providing welds that do not have defects normally associated with fusion welding processes. Friction stir welding (FSW) is a fairly recent technique that utilizes a non consumable rotating welding tool to generate frictional heat and plastic deformation at the welding location, thereby affecting the formation of a joint while the material is in the solid state.

\section{OBJECTIVE AND SCOPE}

The goal of this project is to achieve optimum parameters of material (aluminum) under consideration. To investigate the strength of weld using different tool materials such as mild steel and OHNS steel tool. Defects occur during welding process. 


\section{METHODOLOGY}

The welding tool used in our project is commercially available mild steel \& OHNS steel. The probe is made with the help of machining in lathe. The work-piece used is commercially available aluminium sheet.Following are the chemical composition of tool materials used.

\begin{tabular}{|l|l|}
\hline ELEMENT & CONTENT \\
\hline Carbon & $0.25-0.290 \%$ \\
\hline Copper & $0.20 \%$ \\
\hline Iron & $98.0 \%$ \\
\hline Manganese & $1.03 \%$ \\
\hline Phosphorous & $.040 \%$ \\
\hline Silicon & $.280 \%$ \\
\hline Sulphur & $.050 \%$ \\
\hline
\end{tabular}

Table 1 Composition of mild steel

\begin{tabular}{|l|l|}
\hline ELEMENT & COMPOSITION \\
\hline Carbon & $0.9-1.3 \%$ \\
\hline Chromium & $0.5 \%$ \\
\hline Tungsten & $0.4-0.8 \%$ \\
\hline Manganese & $1.10 \%$ \\
\hline Iron & $96-97.5 \%$ \\
\hline
\end{tabular}

Table 2 Composition of OHNS tool steel

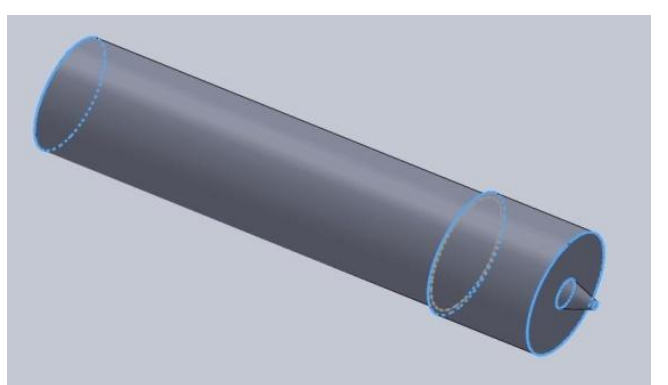

Figure 1 Tool design in Solidworks 2013

\section{EXPIREMENTAL WORK}

Parts are loaded into welder, one in rotating spindle (welding tool) and the other in a stationary clamp (work piece).Components in spindle is brought up to pre-determined rotational speed and then a predetermined axial force is applied.These conditions are maintained for a pre-determined amount of time until desired weld is obtained.Rotational speed is then stopped and increased axial force is applied until desired upset is obtained. Components are then unloaded and cycle is repeated for all tool designs.

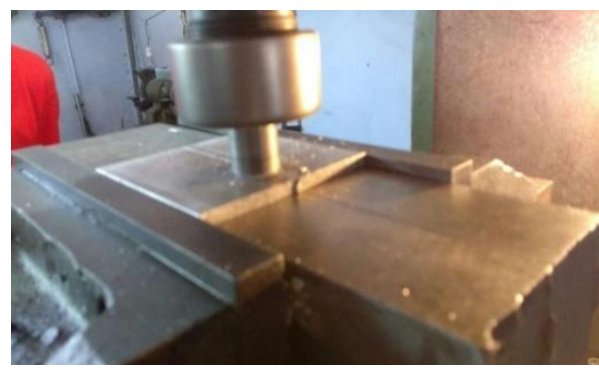

Figure 2 Welding process

In this project we have made study based on shoulder diameter, probe length and type of material used. The strength of weld is measured using Rockwell Hardness test and Vicker's hardness test. Surface temperature is measured using IR thermometer.

\begin{tabular}{|l|l|l|}
\hline Si No. & $\begin{array}{l}\text { Shoulder } \\
\text { diameter }(\mathbf{m m})\end{array}$ & Probe length(mm) \\
\hline 1 & 25 & 6 \\
\hline 2 & 25 & 5 \\
\hline 3 & 25 & 4 \\
\hline 4 & 24 & 4 \\
\hline 5 & 23 & 4 \\
\hline
\end{tabular}

Table 3 Dimensions of mild steel tool

\begin{tabular}{|l|l|l|}
\hline Si No. & $\begin{array}{l}\text { Shoulder } \\
\text { Diameter(mm) }\end{array}$ & Probelength (mm) \\
\hline 1 & 25 & 4 \\
\hline 2 & 24 & 4 \\
\hline 3 & 23 & 4 \\
\hline
\end{tabular}

Table 4 Dimensions of OHNS tool steel

Here tool material has comparatively higher hardness than tool material to be welded. Following is the data showing the hardness of material.

\begin{tabular}{|l|l|l|}
\hline Material & $\begin{array}{l}\text { Rockwell } \\
\text { Hardness (HB) }\end{array}$ & $\begin{array}{l}\text { Vicker Hardness } \\
\text { (HV) }\end{array}$ \\
\hline Aluminium & 57.3 & 125.79 \\
\hline Mild steel & 67.6 & 150.49 \\
\hline OHNS tool & 74.6 & 162.55 \\
\hline
\end{tabular}

Table 5 Hardness valves of materials used

HARDNESS OF WELD USING MILDSTEEL (CONSTANT PROBE LENGTH)

\begin{tabular}{|l|l|l|}
\hline $\begin{array}{l}\text { Shoulder } \\
\text { diameter(mm) }\end{array}$ & $\begin{array}{l}\text { Rockwell } \\
\text { Hardness(HB) }\end{array}$ & $\begin{array}{l}\text { Vicker's } \\
\text { Hardness(HV) }\end{array}$ \\
\hline 23 & 35.5 & 79.21 \\
\hline 24 & 37 & 83.14 \\
\hline 25 & 40 & 99.15 \\
\hline
\end{tabular}

Table 6 Hardness values weld using mild steel tool (Constant probe length)

From the table it is inferred that with the increase in shoulder diameter the hardness of weld 
increases. It may be due to the reason that more surface contact is possible with increase in shoulder diameter and it help in producing sufficient heat for harder weld.

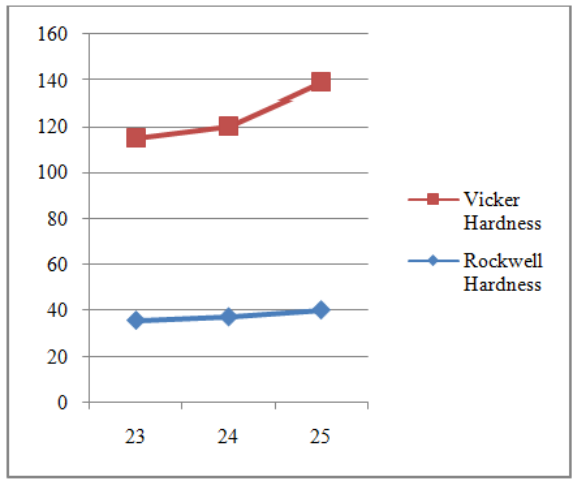

Graph 1 Vickers and Rockwell Hardness of weld using mild steel

\section{HARDNESS OF WELD OBTAINED USING OHNS TOOL (CONSTANT PROBE LENGTH)}

\begin{tabular}{|l|l|l|}
\hline $\begin{array}{l}\text { Shoulder } \\
\text { diameter(mm) }\end{array}$ & $\begin{array}{l}\text { Rockwell } \\
\text { Hardness }(\mathbf{H B})\end{array}$ & $\begin{array}{l}\text { Vicker's } \\
\text { Hardness }(\mathbf{H V})\end{array}$ \\
\hline 23 & 47.3 & 105.5 \\
\hline 24 & 50.3 & 108.85 \\
\hline 25 & 53.67 & 115.71 \\
\hline
\end{tabular}

Table 7 Hardness value of weld obtained using OHNS tool steel

From this table it is inferred that with increase in shoulder diameter the hardness of weld increases. It is also found that tool using OHNS tool steel shows greater hardness as compared mild steel tool.

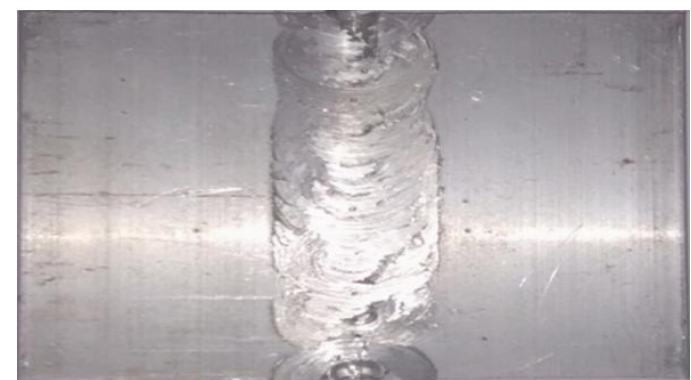

Figure 3 Sample weld obtained using mild steel of $25 \mathrm{~mm}$ shoulder diameter $\& 4 \mathrm{~mm}$ probe Length

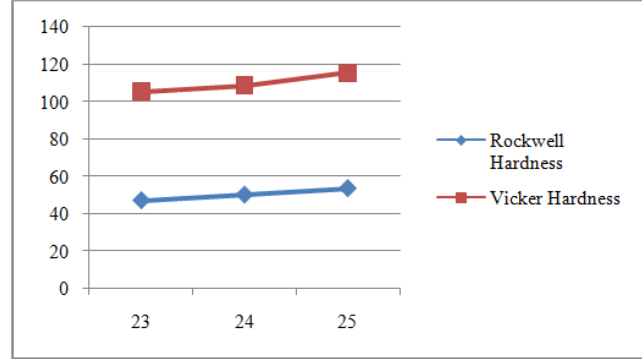

Graph 2 Vickers and Rockwell hardness values of weld obtained using OHNS tool

From the above table and graph it can be inferred that with increase in shoulder diameter the hardness of the weld increases. It may be due to the reason that, more surface contact is possible with larger diameter and it helps in producing sufficient heat for a harder weld.

\section{SURFACE TEMPERATURE OBTAINED USING MILD STEEL TOOL}

\begin{tabular}{|l|l|l|l|l|}
\hline $\begin{array}{l}\text { Distance } \\
\text { Travelle } \\
\text { d(cm) }\end{array}$ & $\begin{array}{l}\text { Temperature for mild steel shoulder } \\
\text { dianeter(mm), } \\
\text { Probe length (min) } \\
{[\mathrm{K}]}\end{array}$ \\
\hline & 23,4 & 24,4 & 25,4 & 25,5 \\
\hline 2 & 366.83 & 368.2 & 373.2 & 375.4 \\
\hline 4 & $\mathbf{3 7 2 . 5}$ & 374.3 & 384.5 & 356.2 \\
\hline 6 & 368.3 & 369.2 & 398.1 & 359.3 \\
\hline 8 & - & - & 397.9 & 379.4 \\
\hline 10 & - & - & 398.1 & 378.3 \\
\hline
\end{tabular}

Table 8 Surface temperature obtained using mild steel tool

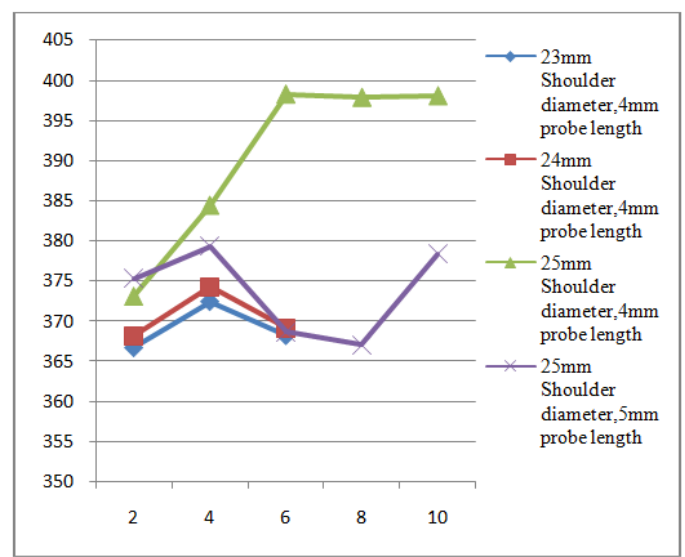

Graph 3 Surface temperature obtained using mild steel tool

From the above table and graph it is evident that with the increasing shoulder diameter the 
temperature on the surface increases. Also increase in temperature is seen as distance travelled by tool is increasing .This may be due to the fact that as tool travels tool get heated and it in turn helps in increasing the overall temperature

\section{SURFACE TEMPERATURE USING OHNS TOOL}

\begin{tabular}{|l|l|l|l|l|}
\hline $\begin{array}{l}\text { Distance } \\
\text { Travelle } \\
\text { d } \\
\text { (cm) }\end{array}$ & $\begin{array}{l}\text { Temperature for mild steel shoulder } \\
\text { diameter(mm), } \\
\text { Probe length (mm) } \\
{[\text { K] }}\end{array}$ \\
\hline & 23,4 & 24,4 & 25,4 & 25,5 \\
\hline 2 & 373.4 & 375.7 & 395.2 & 385.4 \\
\hline 4 & 383.4 & 391.4 & 406.2 & 389.2 \\
\hline 6 & 381.1 & 378.4 & 398.2 & 392.3 \\
\hline 8 & 382.9 & 383.9 & 393.2 & 389.4 \\
\hline 10 & 383 & 382.1 & 396.1 & 388.3 \\
& & & & \\
\hline
\end{tabular}

Table 9 Surface temperature obtained using OHNS steel tool

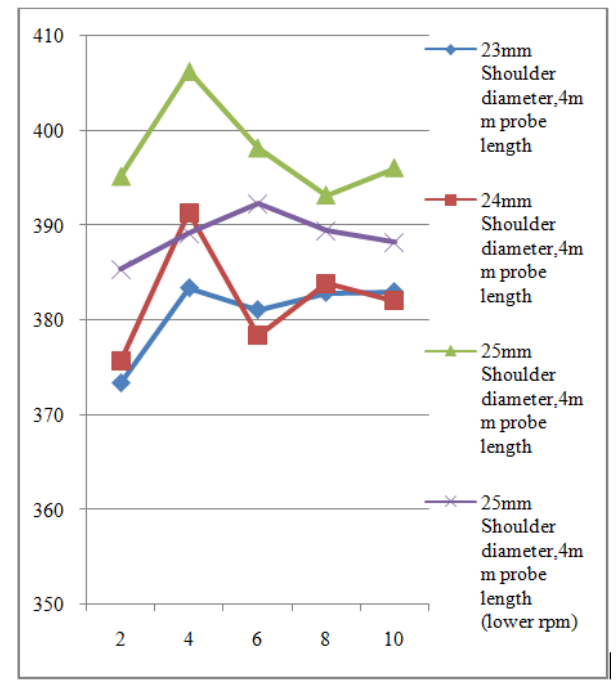

Graph 4 Surface temperature obtained using OHNS steel tool

From the above table it can be inferred that with increasing shoulder diameter and a constant probe length $(4 \mathrm{~mm})$, the temperature generated increases.

\begin{tabular}{|c|c|c|}
\hline COMPARISON & & MAX \\
\hline $\begin{array}{l}\text { TEMPERATURE } \\
\text { TOOLS }\end{array}$ & OBTAINED & BY \\
\hline $\begin{array}{l}\text { SHOULDER } \\
\text { DIAMETER } \\
(\mathrm{mm})\end{array}$ & $\begin{array}{l}\text { Using } \\
\text { mildsteel } \\
\text { Tool(K) }\end{array}$ & $\begin{array}{l}\text { Using } \\
\text { OHNS } \\
\text { tool (K) }\end{array}$ \\
\hline 23 & 372.5 & 384.4 \\
\hline 24 & $\mathbf{3 7 4 . 5}$ & 391.4 \\
\hline 25 & 398.3 & 406.3 \\
\hline
\end{tabular}

Table 10 Comparison of maximum temperature obtained using both the tools

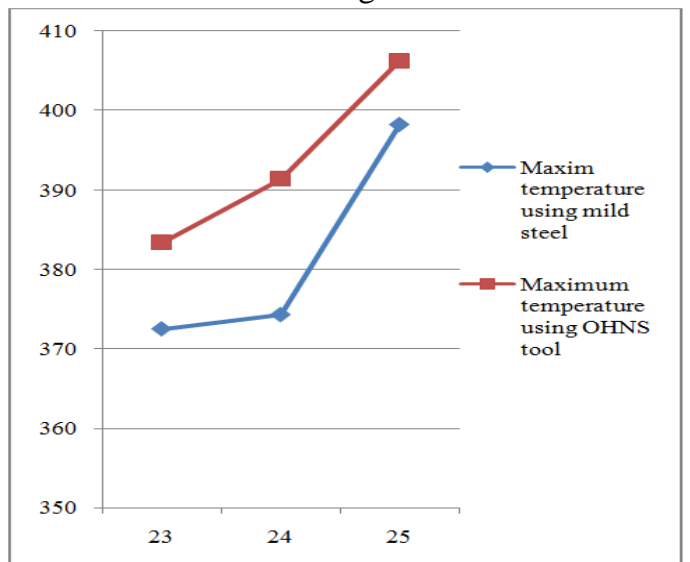

Graph 5 Comparison of maximum temperature obtained using both the tools

The maximum surface temperature obtained for the same shoulder diameter of mild steel \& OHNS tool steel is more than that of mild steel. This is due to the fact that the hardness is more than that of mild steel, which in turn creates more heat and in more mobilization for the material.

$\begin{array}{llcl}\text { COMPARING } & \text { THE } & \text { WELDS OF FRICTION } \\ \text { STIR WELDING } & \& \text { OXYACETYLENE }\end{array}$ WELDING

\begin{tabular}{|l|l|l|}
\hline Variables & $\begin{array}{l}\text { Oxyacetylene } \\
\text { welding }\end{array}$ & $\begin{array}{l}\text { Friction stir } \\
\text { welding }\end{array}$ \\
\hline $\begin{array}{l}\text { Rockwell } \\
\text { hardness }\end{array}$ & 47.21 & 53.61 \\
\hline $\begin{array}{l}\text { Vicker's } \\
\text { Hardness }\end{array}$ & 110.23 & 115.21 \\
\hline
\end{tabular}

Table 11 Comparing the welds of Oxyacetylene welding and Friction stir welding

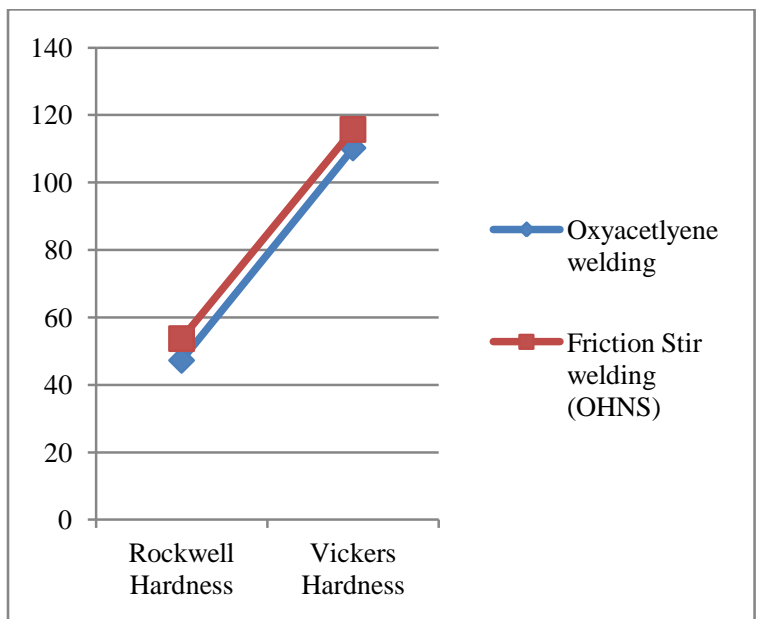

Graph 6 Comparing the welds of Oxyacetylene welding and Friction stir welding

Comparing the two welds the inference obtained is that the hardness of weld using tool of 
$25 \mathrm{~mm}$ shoulder diameter and $4 \mathrm{~mm}$ probelength is slightly better than that of weld obtained using Oxyacetylene welding.

\section{CONCLUSION}

With the increasing shoulder diameter the quality and hardness of the weld increases for both mild steel and OHNS steel tool. With the increase in the probe length the quality and hardness of the weld decreases. The temperature generated on the surface of the material increases with the increase in shoulder diameter for both mild steel and OHNS steel tool. As the hardness of the tool increases the quality, hardness and the temperature generated on the surface of the weld increases.

\section{ACKNOWLEDGEMENT}

The authors would like to thank Department of mechanical Engineering, Jyothi Engineering College, Cheruthuruthy, Kerala, for their technical support and valuable suggestions.

\section{REFERENCES}

[1] A review journal on "FRICTION STIR WELDING AND PROCESSING" by R.S Mishra, Centre for Friction Stir Processing, Institute of Metal Research.

[2] "EXPERIMENTAL STUDY ON FRICTION STIR WELDING OF COPPER METAL" by Y.M. Hwang,P.L. Fan,C.H. Lin, Journal of Materials Processing Technology 210 (2010).

[3] "THE IMPORTANCE OF FRICTION STIR WELDING TOOL", Akos Meilinger, Imre Torok, University of Miskolc, Production Process and Systems, vol.6.(2013)No.1.pp. 25-34.

[4] "THEORITICAL AND EXPIREMENTAL INVESTIGATION OF TRANSIENT TEMPERATURE DISTRIBUTION IN FRICTION STIR WELDING OF AA 702053”, by Dr.Muhsin Jaber Jweeg, Dr.Moneer Hameed Tolephih, Number 6 Volume 18 June2012, Journal of Engineering. 